\title{
Description of the spider Verita williamsi, a new genus and species from Santa Fe, Argentina (Araneae, Gnaphosidae)
}

\author{
Martín J. RAMÍREZ \& Cristian J. GRISMADO \\ División Aracnología, Museo Argentino de Ciencias Naturales "Bernardino Rivadavia”, Av. Angel Gallardo 470, \\ C1405DJR, Buenos Aires, Argentina. (ramirez@macn.gov.ar; grismado@macn.gov.ar)
}

\begin{abstract}
Verita williamsi, new genus and species (Araneae, Gnaphosidae) is described from specimens recently collected in Northern Santa Fe Province, Argentina. The peculiar combination of having only two piriform gland spigots, aligned setae on the leg scopulae, and anterior lateral spinnerets not widely spaced suggests that the species is probably a close relative of Micaria and some of the small representatives of the Anzacia group of genera. It differs from all of them by having three teeth in the cheliceral retromargin and lacking iridescent squamose scales in the abdomen.
\end{abstract}

Key words: Ground spiders, taxonomy, Argentina, spinneret morphology.

Resumen: Verita williamsi, nuevo género y especie (Araneae, Gnaphosidae) se describe a partir de especímenes colectados recientemente en el norte de la provincia de Santa Fe, Argentina. Estas arañas muestran una peculiar combinación de caracteres, solamente dos fúsulas de glándulas piriformes, setas alineadas en la escópula de las patas y las hileras anteriores no muy apartadas entre ellas, que sugieren que la especie está cercanamente emparentada a Micaria y a algunos de los representantes pequeños del grupo de géneros Anzacia. Se distingue de todos ellos por tener tres dientes en el retromargen queliceral y por carecer de setas escamosas iridiscentes en el abdomen.

Palabras clave: Arañas del suelo, taxonomía, Argentina, morfología de hileras.

\section{INTRODUCTION}

The gnaphosid spider fauna of South America has a great level of endemicity; of the 25 genera reported from the region, 13 are exclusive endemics. The recent synopsis of gnaphosid genera by Murphy (2007) expedited the discovery of some of these endemic genera from southern Brazil (e.g., Ott 2012, 2014; Ott \& Brescovit 2012), and allowed to appreciate the regional diversity in a global perspective. Of the 14 groups of genera proposed by Murphy, only six (Zelotes, Laronius, Herpyllus, Echemus, Leptodrassex and Hemicloea groups) are well represented in South America and make the bulk of gnaphosid diversity in the region; of the remaining groups, eight are not represented in South America (except by a few, probably misplaced species of Drassodes Westring). We report here a new gnaphosid species from Argentina, extremely atypical and seemingly unrelated with any of the groups present in South America. The specimens were collected in an expedition to the northern part of Santa Fe province, by a team from the Division of Arachnology of the Museo Argentino de Ciencias Naturales. As shown by the progress in the digitization of the National Collection of Arachnology, the northern part of Santa Fe, although extremely diverse, is only superficially sampled for spiders.

\section{MATERIAL AND METHODS}

Specimens are deposited in the Arachnological Collection of the Museo Argentino de Ciencias Naturales "Bernardino Rivadavia", Buenos Aires, Argentina (MACN-Ar, Cristina L. Scioscia and Martín J. Ramírez). Drawings were made using a camera lucida mounted on a Leitz stereoscopic microscope or an Olympus BH-2 compound microscope. The internal genitalia were cleared in clove oil. Photographs of the preserved specimens were taken with a Leica DFC 290 digital camera mounted on a Leica M165 C stereoscopic microscope, and the focal planes were composed with Helicon Focus 4.62.2. Scanning electron mi- 
crographs were taken under high vacuum with a FEI XL30 TMP after critical point drying and gold-palladium coating. All measurements are in millimeters. Abbreviations and terminology follow, where possible, Platnick \& Shadab (1988); only surfaces bearing spines listed. Laboratory procedures to obtain the DNA barcode were performed at the barcoding molecular laboratory of the Museo Argentino de Ciencias Naturales "Bernardino Rivadavia". Genomic DNA was extracted from one leg following a glass fiber-based extraction protocol developed by Ivanova et al. (2006). A primer cocktail including the Folmer (Folmer et al. 1994) and Lep (Hebert et al. 2004) primers was used to perform the polymerase chain reaction (PCR). The PCR mix consisted of $825 \mu \mathrm{l}$ water, $125 \mu \mathrm{l} 10 \mathrm{X}$ buffer, $62.5 \mu \mathrm{l} \mathrm{MgCl}_{2}(25$ $\mathrm{mM}), 6.25 \mu \mathrm{l} \mathrm{dNTP}(10 \mathrm{mM}), 6.25 \mu \mathrm{l}$ of each primer $(0.01 \mathrm{mM})$ and $6.25 \mu \mathrm{l}$ Taq DNA polymerase (5 $\mathrm{U} / \mathrm{ml}$ ), for a total volume of $10.5 \mu \mathrm{l}$ (to which we added $2 \mathrm{ul}$ of genomic DNA). The PCR reaction profile included an initial denaturation at $94^{\circ} \mathrm{C}$ for $2 \mathrm{~min}, 5$ cycles of $94^{\circ} \mathrm{C}$ for $30 \mathrm{sec}$, annealing at $45^{\circ} \mathrm{C}$ for $40 \mathrm{sec}$, and extension at $72^{\circ} \mathrm{C}$ for $1 \mathrm{~min}$, 35 cycles of $94^{\circ} \mathrm{C}$ for $30 \mathrm{sec}$, annealing at $51^{\circ} \mathrm{C}$ for $40 \mathrm{sec}$, and extension at $72^{\circ} \mathrm{C}$ for $1 \mathrm{~min}$, and a final extension at $72^{\circ} \mathrm{C}$ for $10 \mathrm{~min}$. Amplicons were visualized on $2 \%$ agarose $\mathrm{E}-\mathrm{GelH} 96$-well system (Invitrogen). Sequencing was performed at the Canadian Centre for DNA Barcoding (CCDB), Ontario following standard procedures, and analyzed with the default values of BOLD Systems Public Data Portal (http://www.boldsystems. org/). Sequences were deposited in the project Spiders of Argentina of the Barcode of Life Data Systems (BOLD; Ratnasingham and Hebert 2007) along with the specimen information.

\section{SYSTEMATICS}

\section{Family GNAPHOSIDAE Genus Verita gen. nov.}

Type species: Verita williamsi n. sp., by monotypy.

Etymology: The generic name is noun in apposition, taken from a diminutive of Vera, the department where the type locality is located.

Diagnosis: Verita differs from most other gnaphosid genera in having the ALS with their bases relatively close to each other (Fig. 2E), only two piriform spigots (Figs. 4B, 5B), and the foreleg scopulae with relatively large setae in two lines (Figs. 3A-C). The only genera with this combination of characters are Micaria and some small representatives of the Anzacia group such as Nauhea and Homoehothele (which are also similar in overall morphology). Verita differs from all of them having three teeth in the cheliceral retromargin (Fig. 6D; one in Nauhea and two in Homoeothele), and lacking iridescent squamose scales in the abdomen. It also differs from Micaria by having normal, large eyes.

Description: Small sized gnaphosids (total length 2.33-2.79). Carapace elongate oval in dorsal view (Figs. 1C, 2C), widest at rear of coxae II, gently narrowed at level of palpal insertion, cephalic area elevated, thoracic area with abruptly sloping; thoracic groove short, posterior to declivity; color chestnut brown; all carapace covered with needle-like setae, mostly forwardly oriented. Eyes: from above, anterior eye row slightly recurved, posterior eye row almost straight; from front, both rows strongly procurved (Figs. 1D, 2D); AME circular, dark, PME obliquely rectangular, with silvery oblique tapeta at $90^{\circ}$, ALE and PLE oval, silvery; eyes subequal in size, PLE slightly smaller; all eyes about evenly spaced except ALE nearly touching AME; MOQ longer than wide. Clypeal height less than AME diameter. Chelicerae with three small retromarginal teeth (Fig. 6D), promargen untoothed. Endites rectangular, with oblique depression shallow; labium nearly trapezoidal, almost as long as its basal width, distally truncated; sternum nearly heart shaped, longer than wide, pointed behind coxae IV. Legs: spination reduced (see under species description) metatarsi without preening combs. Podomeres pale brown, femora darker. Scopulae composed of spatullate tenent setae in two lines, from distal end of metatarsi to distal tarsi I and II (Fig. 3A-C), absent on III and IV. Tarsi IV pseudosegmented in both sexes. Claw tufts composed of three spatullate setae on each side, with wide bases on a common socket (Fig. 3F, G). Claws pectinate, claw-tuft clasper not found. Leg articles and body with feathery scales (Fig. 3C). Tarsal organ capsulate, with small round aperture (Fig. 3E). Trichobothria with transversal ridges on anterior hood, shaft with basal bulbous expansion with bumps (Fig. 3D). Abdomen of male with dorsal oval scutum slightly sclerotized, covering nearly one third of dorsal surface (Fig. 1A), without epiandrous spigots (Fig. 5F). Coloration: dorsum uniformly brown except by four spots of whitish setae, one on the center, two laterodorsal converging bands, and one larger, oval, patch above the spinnerets; venter pale, more sclerotized on the epigastric area of the males; incomplete dark ring around 

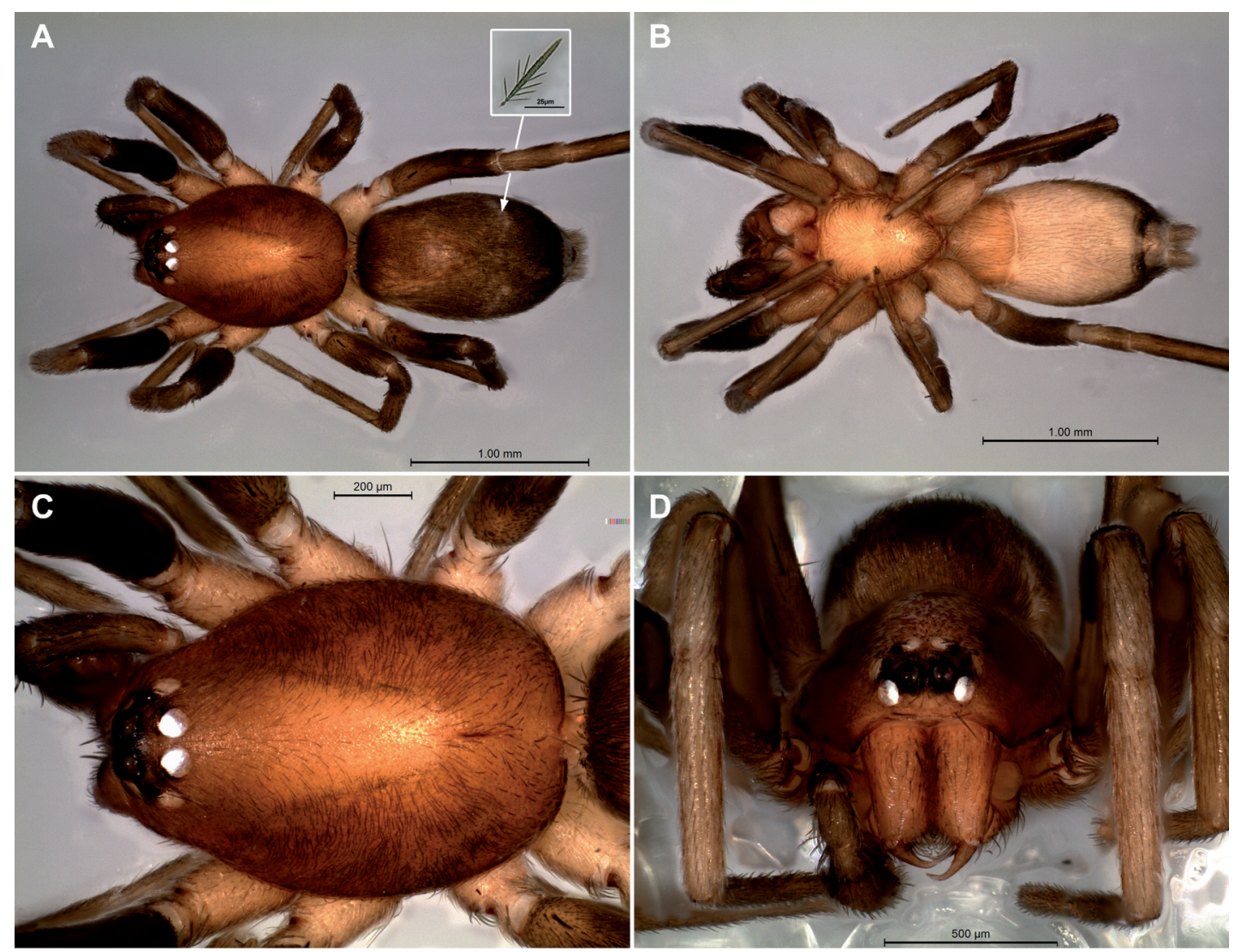

$\mathbf{E}$

Fig. 1. Verita williamsi sp. nov., male holotype. A habitus dorsal view (inset to feathery seta of the abdomen), $\mathbf{B}$ same, ventral view, $\mathbf{C}$ carapace, dorsal view, $\mathbf{D}$ habitus, anterior view, $\mathbf{E}$ illustrative barcode of COI (paratype MACN-Ar 32193).

the spinnerets. Tracheal spiracle small, just before spinnerets (Fig. 4A). Spinnerets: Anterior lateral spinnerets with basal article tronco-conical, separated from each other by less than their diameter, distal article only represented by setae at sides of major ampullate field; major ampullate spigots on mesal margin, two piriform spigots on inflatable membranous area, with shaft well differentiated from base (Figs. 4A, B, 5 A, B). Cylindrical gland spigots in female, slightly larger than minor ampullate gland spigots, three in a single line on posterior median spinnerets, and two on posterior lateral spinnerets (Fig. 4C, D). Aciniform spigots small, present on posterior spinnerets of male and female (Figs. 4C, D, $5 \mathrm{C}-\mathrm{E})$. Modified spigot of posterior lateral spinnerets in center of spinning field, atrophied in male (Figs. 4D, 5E). Genitalia: Male palp with simple, pointed retrolateral tibial apophysis (Fig. $6 \mathrm{C})$; copulatory bulb with simple looping sperm duct, median apophysis simple, hook-shaped, ar- ticulate, embolus short and thick, articulate (Fig. 6A-C). Epigyne with anterior hood and narrow median field, secondary spermathecae small, large anterior seminal receptacle and complex primary spermathecae; Bennet's glands small, everted (Fig. 6E, F).

\section{Verita williamsi, new species}

(Figs. 1-6)

Type material. Male holotype and female paratype from Argentina: Santa Fe: Vera: Estancia Las Gamas, margin of flooded area on Ruta Nacional 98, $16.5 \mathrm{~km}$ (air) W Vera, S $29.41382^{\circ} \mathrm{W} 60.37438^{\circ}$ (GPS, +-150m), elev. 23 m (GPS), 19-24.Mar.2014, manual collecting on base of Cyperus laetus (Fig. 7A, B), M. Ramírez, C. Grismado, L. Piacentini \& M. González Márquez (MJR-Loc-160), deposited in MACNAr 31357; collected in copula. Paratypes: same data, 2 males, 1 female, together with 2 juveniles 

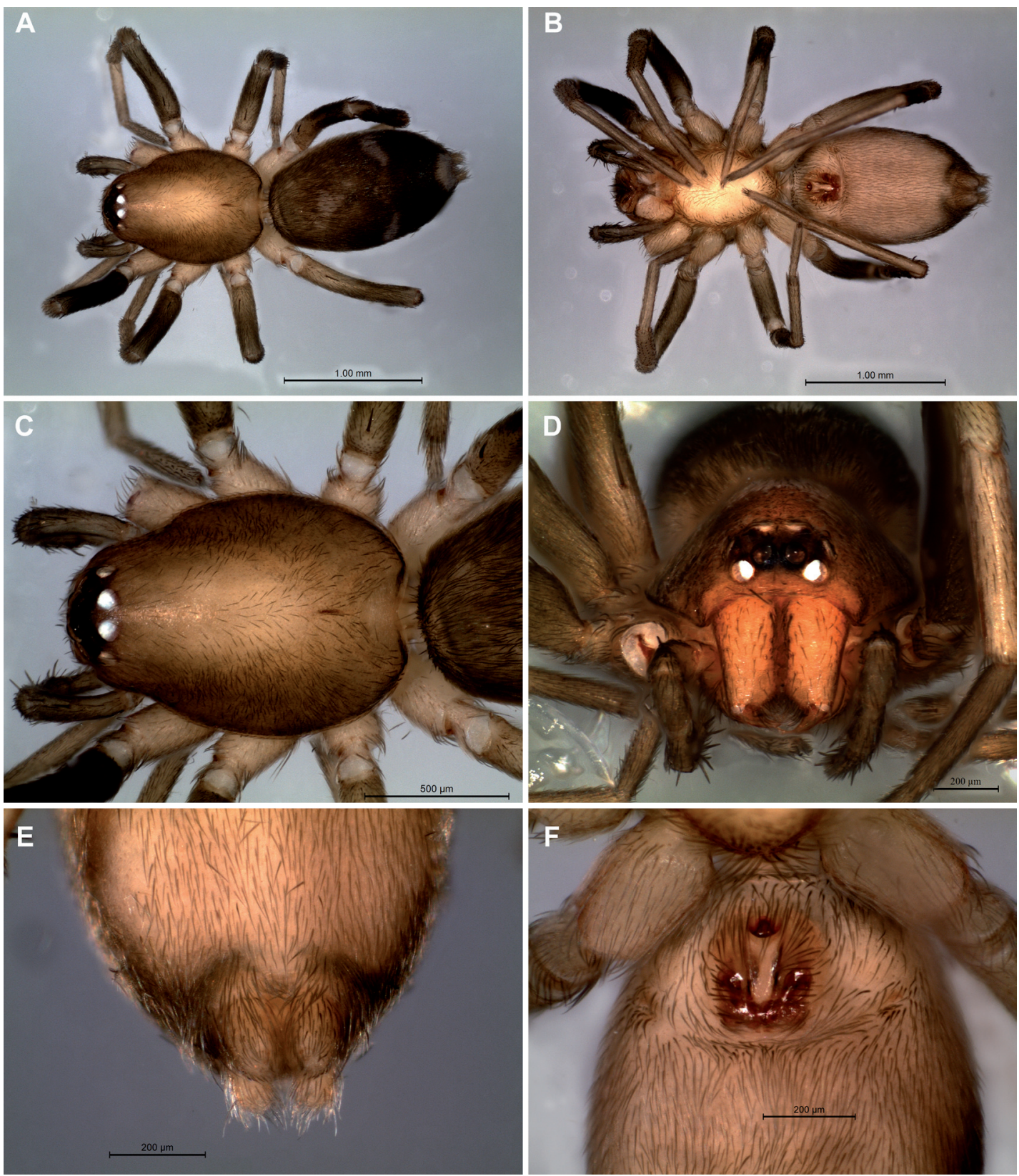

Fig. 2. Verita williamsi sp. nov., female paratype (MACN-Ar 31357). A habitus dorsal view, B same, ventral view, $\mathbf{C}$ carapace, dorsal view, $\mathbf{D}$ habitus, anterior view, $\mathbf{E}$ spinnerets, ventral view, $\mathbf{F}$ epigynum, ventral view.

(MACN-Ar 31356), 1 male (MACN-Ar 32193, tissue sample CJG-3242/MLB 00751, BOLD Process ID SPDAR842-14).

Etymology. The specific epithet is a patronymic in honor to the Fundación Williams, for its important and continued support in the digitization and conservation of the scientific collections of the Museo Argentino de Ciencias Naturales.
Diagnosis. As for the genus.

Description. Male (holotype, Figs. 1, 6A-C): Total length 2.46. Carapace 1.16. Femur II 0.861. Eye sizes and interdistances: $\mathrm{AME}$ 0.0678, ALE 0.0646, PME 0.0795, PLE 0.0667; AME-AME 0.0171, AME-ALE almost touching, PME-PME 0.0277, PME-PLE 0.0469, ALE-PLE 0.0331; MOQ length 0. 205, front width 0.191, 


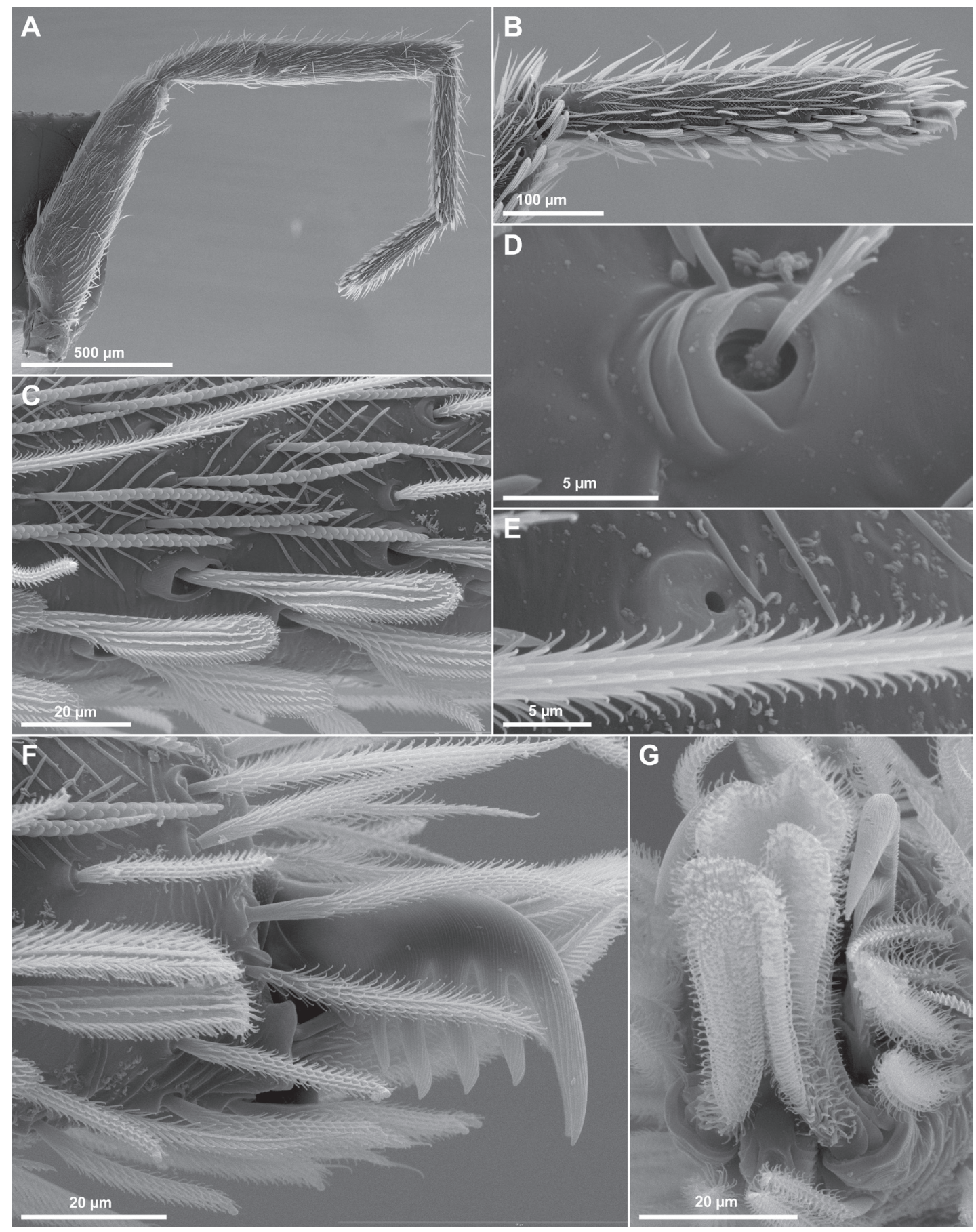

Fig. 3. Verita williamsi sp. nov., female leg I structures, scanning electron microscope. A left leg I, prolateral view, B same, detail of tarsus, C same, detail of tarsal scopula and feathery scales, D tarsal trichobothria, $\mathbf{E}$ tarsal organ, $\mathbf{F}$ tarsal claws and claw tuft, prolateral view, $\mathbf{G}$ same, apical view.

back width 0.191 . Leg spination: pattern (only surfaces bearing spines listed): male: femora: I-IV dl-0-0; tibiae: III p1-1, r1subap, v1-0-2ap, IV p1-1, r1subap, v2-0-2ap; metatarsi III p1-1ap, r11ap, v1-2ap, IV p1-1, r1-1ap, v2-2-2ap. Spinnerets (spigots from MACN-Ar 31358): Anterior lateral 

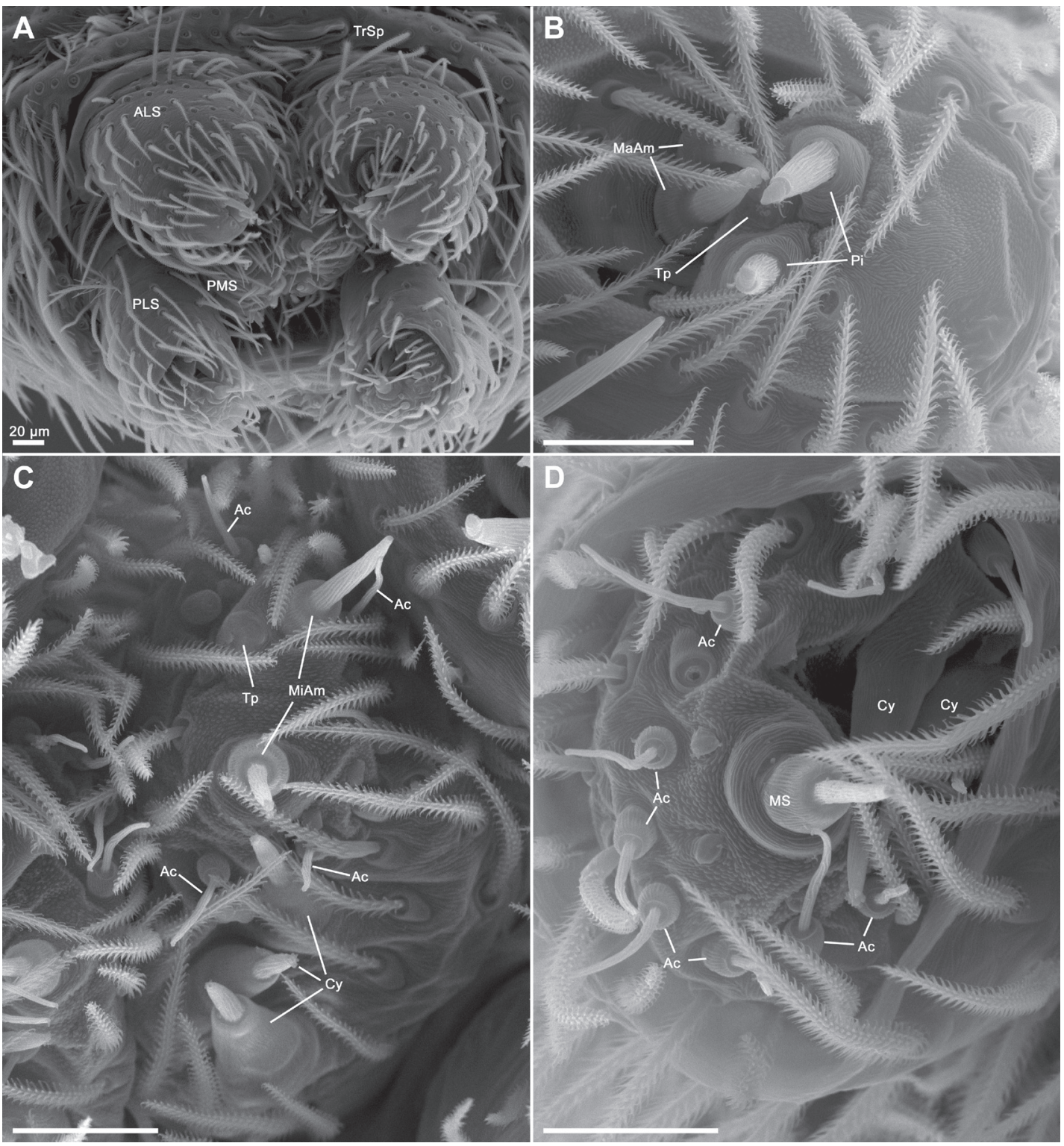

Fig. 4. Verita williamsi sp. nov., female spinnerets, scanning electron microscope. A overview of spinnerets, B left anterior lateral spinneret, $\mathbf{C}$ left posterior median spinneret, $\mathbf{D}$ right posterior lateral spinneret. (Ac = aciniform gland spigot; ALS = anterior lateral spinneret; $\mathrm{Cy}=$ cylindrical gland spigot; MaAm = major ampullate gland spigot; MiAm = minor ampullate gland spigot; $\mathrm{MS}=$ modified spigot of PLS; Pi = piriform gland spigot; PLS = posterior lateral spinneret; PMS = posterior median spinneret; $\mathrm{Tp}=$ tartipore of ampullate gland spigot; $\mathrm{TrSp}=$ tracheal spiracle).

spinnerets with one thin ampullate gland spigot and a posterior nubbin (Fig. 5B). Posterior median spinnerets with one minor ampullate gland spigot, plus a nubbin in a common mound with a large tartipore, and about six aciniform gland spigots (Fig. 5C, D). Posterior lateral spinnerets with atrophied modified spigot, and about 7 aciniform spigots (Fig. 5 E). Genitalia: palp with retrolateral tibial apophysis pointed, slightly curved, displaced to dorsal side (Fig. 6C); bulb with simple looping sperm duct, with small hook-shaped median apophysis arising from non sclerotized area, embolus origin on the prolateral side of tegulum, articulating on dark tegular knob; embolus ribbon-like, with two consecutive marginal extensions, the distal one nearly trans- 

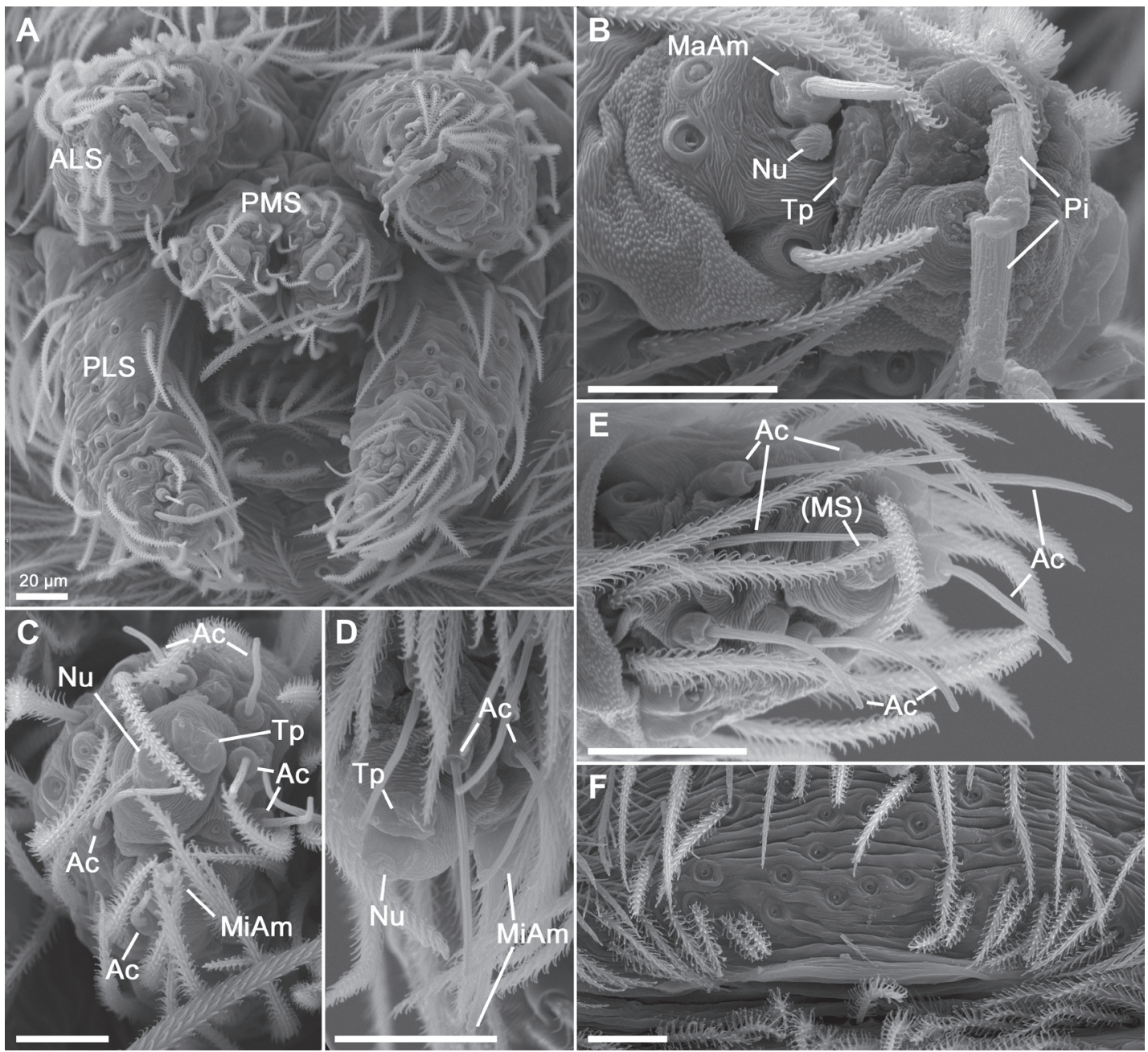

Fig. 5. Verita williamsi sp. nov., male spinnerets, scanning electron microscope. A overview of spinnerets, B left anterior lateral spinneret, C, D right posterior median spinneret, E right posterior lateral spinneret, F epiandrum. (Ac = aciniform gland spigot; ALS = anterior lateral spinneret; MaAm = major ampullate gland spigot; MiAm = minor ampullate gland spigot; $(\mathrm{MS})=$ nubbin of modified spigot of PLS; Nu = nubbin of ampullate gland spigot; $\mathrm{Pi}=$ piriform gland spigot; PLS = posterior lateral spinneret; PMS $=$ posterior median spinneret; $\mathrm{Tp}=$ tartipore of ampullate gland spigot; $\operatorname{TrSp}=$ tracheal spiracle).

lucent; embolus tip fitting in small concavity of distal retrolateral part of tegulum, with elevated borders (Fig. 6A-C).

Female (paratype MACN-Ar 31357, Fig. 2): Total length 2.52. Carapace 1.14. Femur II 0.745 long. Eye sizes and interdistances: AME 0.0736, ALE 0.0725, PME 0.0804, PLE 0.0569; AMEAME 0.04, AME-ALE 0.01, PME-PME 0.0324, PME-PLE 0.0457, ALE-PLE 0.0444; MOQ length 0. 207, front width 0.181 , back width 0.187 . Leg spination: (only surfaces bearing spines listed) femora: I-IV dl-0-0; tibiae: III p1-1, v1-2ap, IV p1-1, r1-1subap, v2-2ap; metatarsi III p1-1ap, r1-1ap, v1-2ap, IV p1-0-1ap, r1-0, v2-22ap. Spinnerets (spigots from MACN-Ar 31355): Anterior lateral spinnerets with two ampullate gland spigots (Fig. 4B). Posterior median spinnerets with two minor ampullate gland spigots, one of them flanked by a large tartipore, about four aciniform gland spigots, and three cylindrical spigots on a longitudinal line on posterior end (Fig. 4C). Posterior lateral spinnerets with two cylindrical gland spigots on mesal margin, a modified spigot, and about 10 aciniform spigots (Fig. 4 D). Epigyne with narrow median field, flanked by two posterolateral blind concavities 
A

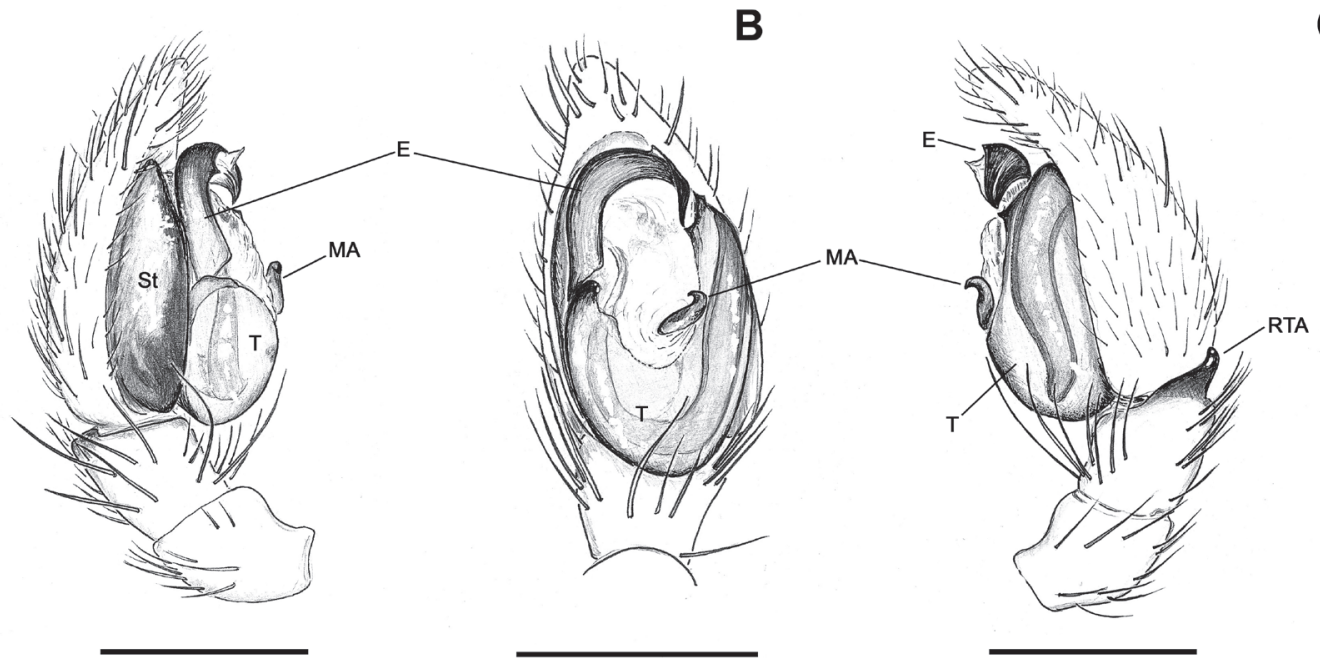

D

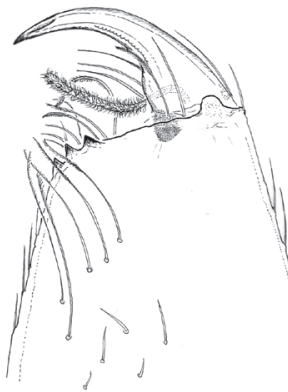

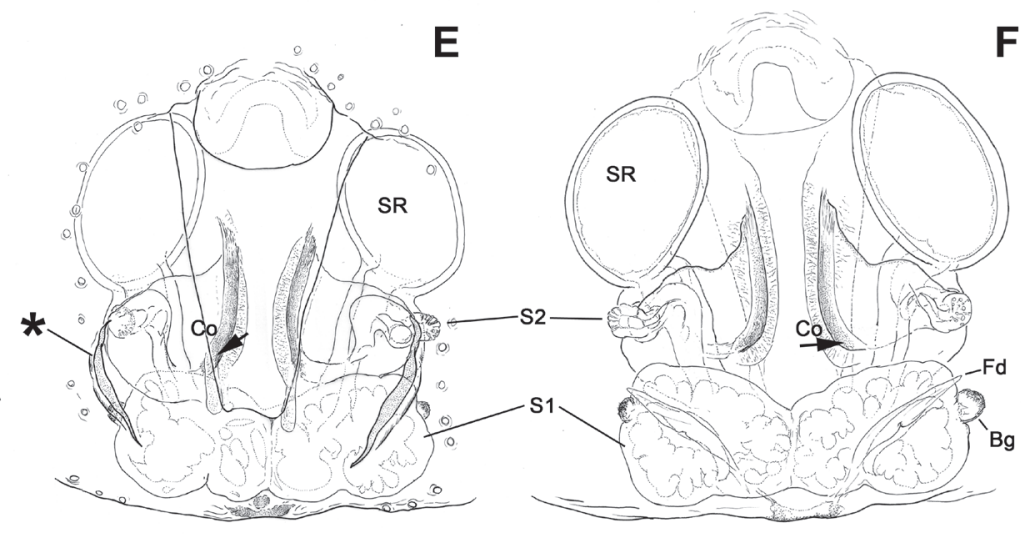

Fig. 6. Verita williamsi sp. nov., A-C male holotype, left palp. A prolateral view, B ventral view, C retrolateral view D, male MACN-Ar 31358, left chelicera, retromargin. E-F female MACN-Ar 31355 vulva, cleared. $\mathbf{E}$ ventral view, $\mathbf{F}$ dorsal view. Abbreviations: $\mathrm{Bg}=$ Bennet's gland, $\mathrm{Co}=\mathrm{Copulatory}$ opening, $\mathrm{E}=$ embolus, $\mathrm{Fd}=$ fertilization duct, $\mathrm{MA}=$ median apophysis, $\mathrm{RTA}=$ retrolateral tibial apophysis, $\mathrm{S} 1=$ primary spermatheca, $\mathrm{S} 2=$ secondary spermatheca, $\mathrm{SR}=$ seminal receptacle, $\mathrm{St}=$ subtegulum, $\mathrm{T}=$ tegulum, asterisk $=$ posterolateral blind concavitiy. Scale bars A-C $0.2 \mathrm{~mm}, \mathbf{D}-\mathbf{F} 0.1 \mathrm{~mm}$.

with curved, elevated borders. Wide copulatory openings leading to lateral, small secondary spermathecae; the copulatory duct continues to a common, large longitudinal duct that connects the anterior, large and oval seminal receptacle with the posterior, complex primary spermathecae from where the fertilization ducts arise; small, everted Bennet's glands placed laterally (Fig. 6E, F).

Distribution. Known only from northern Santa Fe Province, Argentina.

Other material examined. Same data as the types, 1 female (MACN-Ar 31355, preparations MJR 1504-1506, CJG 1491), 1 male (MACN-Ar
31358, preparations MJR 1502-1503. Santa Fe: General Obligado: old bridge, $1.7 \mathrm{~km}$ SW Berna, S $29.28495^{\circ} \mathrm{W} 59.86164^{\circ}$ (GPS, +-50m), elev. $32 \mathrm{~m}$ (GPS), 23.Mar.2014, grassland with Coleataenia prionitis and palm trees (Fig. 7C), manual collecting, M. Ramírez, C. Grismado, L. Piacentini \& M. González Márquez (MJR-Loc-164) 1 male, 1 juvenile (MACN-Ar 31437); 1 male, 1 juvenile (MACN-Ar 31438).

Natural history. All the specimens were collected on the base of plants in flooded areas (Fig. 7).

Barcode. Standard barcode with COI of male paratype MACN-Ar 32193 (Fig. 1E): 

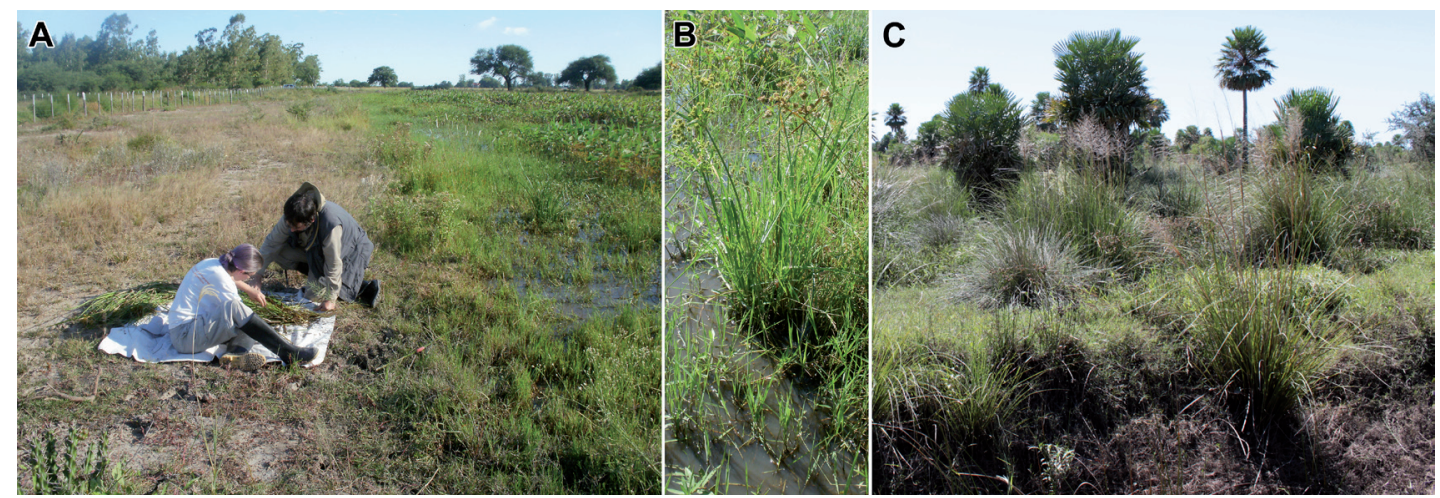

Fig. 7. Habitats of Verita williamsi. A. Type locality, showing sorting of plants at margin of flooded area (collectors Luis Piacentini and María Eugenia González Márquez in photo). B. Plant of Cyperus laetus, where the specimens were colleted. C. Grassland with Coleataenia prionitis and palm trees near Berna; the specimens were collected at the base of the large grasses $C$. prionitis.

ACTTTGTATTTATTGTTTGGTTCATGATCCGCTATAGTTGGGACAGCAATAAGAGTACTAATTCGTATAGAATTAGGGCAATCTGGAAGATTGCTAGGAGATGATCATTTATATAATGTTATTGTTACTGCACATGCTTTTGTTATAATTTTTTTTATAGTTATACCTATTTTAATTGGTGGATTTGGAAATTGATTAGTTCCTTTAATGTTAGGAGCTCCTGATATAGCTTTTCCTCGTATAAATAATTTAAGTTTTTGGTTATTACCTCCGTCATTGATTTTATTATTTATTTCTTCTATGGCTGAAATAGGGGTTGGGGCAGGATGGACAGTATATCCTCCTTTAGCTGCTAATATAGGTCATGCTGGTAGAGCTATGGATTTTGCAATTTTTTCTTTGCATTTGGCTGGGGCTTCTTCTATTATAGGTGCTATTAATTTTATTTCTACTATTATTAATATGCGTTCATTAGGAATGAGAATGGAAAGGGTTTCTTTATTTGTTTGATCAGTTTTTATTACTGCCATTTTATTGTTATTATCTTTACCTGTATTAGCAGGTGCTATTACTATATTGTTAACAGATCGTAATTTTAATACATCTTTTTTTGATCCTGCTGGAGGAGGAGATCCAATTTTATTTCAACATTTATTT

\section{DISCUSSION AND CONCLUSIONS}

The anterior lateral spinnerets of the new species Verita williamsi are very atypical for a gnaphosid. While in gnaphosids these spinnerets are cylindrical and widely spaced (Platnick 1990: fig. 1), in Verita are tapering and moderately spaced (Figs. 2E, 4A). A close examination of their spinnerets reveals the reduction of the terminal article of those spinnerets, typical of gnaphosids and prodidomids (Platnick 2002; see also Ramírez 2014, character 247). The piriform spigots lack the accompanying setae typical of prodidomids (Platnick 1990), but have a cylindrical shaft, well defined by a sharp transition from the base, differing from the widened shafts of common among gnaphosids (see Platnick 1990, and Ramírez 2014: character 263). Only few gnaphosid genera were reported with this morphology of piriform spigots (e.g., Platnick 1990: figs. 80, 86), and among these, Micaria and the Anzacia group as proposed by Murphy (2007) coincide in other characters as well: a small number of piriform spigots (one in Micaria, two in Homoeothele and Nauhea), and the leg scopulae made of relatively large setae in two lines, as in Micaria. Other than that, the genus Verita has a rather generalized morphology, lacking the derived characters of other, better diagnosed groups of gnaphosids. Their simple palps and female genitalia are similar as in many gnaphosids, including the males of some Micaria, and both sexes Homoeothele micans Simon, which also has a blind seminal receptacle in the female vulva (Fig. $6 \mathrm{E}$, and see Murphy 2007: 561). The only significant difference with these groups is the absence in Verita of the iridescent squamose scales characteristic of Micaria and the Anzacia group; instead, their scales are of the feathery type (Fig. 1A), widespread in Gnaphosidae (see Zakharov and Ovtsharenko 2015). The suggested relationships of Verita are biogeographically interesting: the Micaria group is only known from the Holarctic, with a few dubious records in South Africa, India and Australia, while the genera in the Anzacia group are known from Australia, New Caledonia and New Zealand (Murphy 2007).

An identification search in BOLD Systems (www.boldsystems.org/, performed 10 Aug 2015) did not retrieve similar sequences that might be considered congeners or conspecifics. The closer match (89\% similarity) is from an earlyrelease sample of Herpyllus sp. (Gnaphosidae) from Arizona, USA. A search for all records of gnaphosoid families in BOLD retrieved a closer match with Micaria foxi Gertsch, 1933, at 85\% similarity. A similar search on GenBank using BLAST (Zhang et al. 2000; https://blast.ncbi. nlm.nih.gov/, performed 19 Nov 2015) retrieved exemplars from several families in the top-rank (mainly Gnaphosidae, but also other families such as Anyphaenidae, Phrurolithidae, Trachelidae, Clubionidae, Sparassidae, with $88-89 \%$ similari- 
ty). The closest matches are specimens of Zelotes rainier Platnick \& Shadab (GenBank accessions KP650046, KP651402) and an unidentified spider from New Zealand (KP422419). Eight species of Micaria had 86-89\% sequence similarity. None of these databases contain sufficient coverage to clarify the relationships of Verita, but both are compatible with a close relatedness with Micaria.

\section{ACKNOWLEDGMENTS}

We thank to the authorities of the Dirección General de Recursos Naturales y Ecología, Secretaría de Medio Ambiente, Secretaría de Medio Ambiente de la Provincia de Santa Fe by extending the collection permits, especially to Gabriel Marteleur. The Ministerio de la Producción de la Provincia de Santa Fe, Raúl Villasboas and Ivan Frigeri are deeply acknowledged for hospitality and facilities during our stay in Estancia Las Gamas for fieldwork. Our co-collectors assisted and provided photographs during the field work, and Mirta Arriaga and Mónica Stampacchio (MACN) provided identification of plants. Norman Platnick and Vladimir Ovtsharenko gave useful taxonomic comments on images of the specimens, and Facundo Labarque provided useful comments in a previous version of the manuscript. Mariana Barone and Darío Lijtmaer helped with the processing of barcode samples, and the Canadian Centre for DNA Barcoding (CCDB) produced the sequences. Fundación Williams provided generous support for digitization of collections and the Argentinian iBOL Fund. This work was supported by grants PICT 20111007 from FONCyT, and Fondo Fondo iBOL Argentina 2012 from CONICET.

\section{REFERENCES}

Folmer O., Black M., Hoeh W., Lutz R. \& Vrijenhoek R. 1994. DNA primers for amplification of mitochondrial cytochrome c oxidase subunit I from diverse metazoan invertebrates. Molecular Marine Biology and Biotechnology 3: 294-299.

Forster, R. R. 1979. The spiders of New Zealand. Part V. Cycloctenidae, Gnaphosidae, Clubionidae. Otago Museum Bulletin 5: 1-95.

Hebert P. D. N., Penton E. H., Burns J. M., Janzen D. H. \& Hallwachs W. 2004. Ten species in one: DNA barcoding reveals cryptic species in the neotropical skipper butterfly Astraptes fulgerator. Proceedings of the National Academy of Sciences USA 101: 14812-14817.

Ivanova N. V., deWaard J. R. \& Hebert P. D. N. 2006. An inexpensive, automation-friendly protocol for recovering high-quality DNA. Molecular Ecology Notes 6: 998-1002.

Murphy, J. 2007. Gnaphosid genera of the world. British Arachnological Society, St Neots, Cambs, 1:i-xii, 1-92; 2:i-11, 93-605.

Ott, R. 2012. Neodrassex, a new genus of the Leptodrassex group (Araneae, Gnaphosidae) from South America. Iheringia, Série Zoologia 102: $343-350$.

Ott, R. 2014. Nopyllus, a new South American Drassodinae spider genus (Araneae, Gnaphosidae). Iheringia, Série Zoologia 104: 252-261.

Ott, R. \& Brescovit, A. D. 2012. Arauchemus, a new spider genus of the Echemus group (Araneae: Gnaphosidae: Echeminae) from araucaria forest areas in southern Brazil, with notes on habitat preferences and phenology. Zootaxa 3339: 44-56.

Platnick, N. I. 1990. Spinneret morphology and the phylogeny of ground spiders (Araneae, Gnaphosoidea). American Museum Novitates 2978: 1-42.

Platnick, N.I. 2002. A revision of the Australasian ground spiders of the families Ammoxenidae, Cithaeronidae, Gallieniellidae, and Trochanteriidae (Araneae: Gnaphosoidea). Bulletin of the American Museum of Natural History 271: 1-243.

Platnick, N. I. \& Shadab, M. U. 1988. A revision of the American spiders of the genus Micaria (Araneae, Gnaphosidae). American Museum Novitates 2916: 1-64.

Ratnasingham, S. \& Hebert, P. D. N. 2007. BOLD: The barcode of life data system (www.barcodinglife. org). Molecular Ecology Notes 7: 355-364.

Zakharov, B. \& Ovtsharenko, V. 2015. The covering setae of ground spiders (Araneae: Gnaphosidae). Arachnologische Mitteilungen 49: 34-46.

Zhang, Z., Schwartz, S., Wagner, L., \& Miller, W. 2000. A greedy algorithm for aligning DNA sequences. Journal of Computational Biology 7: 203-14. 